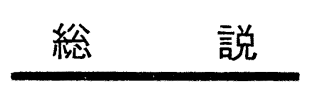

\title{
ライフサイエンスと油化学
}

松宮弘幸

野村総合研究所 生物科学研究部

(鎌 倉 市梶原 16000 )

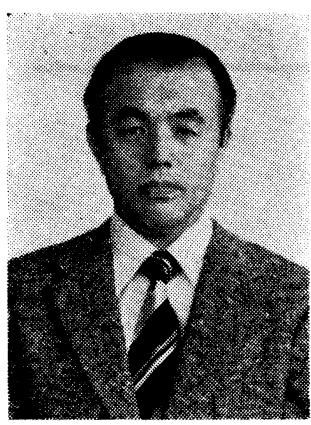

\section{Advancement of Life Sciences and Oil Chemistry}

\author{
Hiroyuki Matsumiya
}

\section{1 はじめに}

外国語の単語がわが国に帰化した数多くの外来語があ るが「ライフサイエンス」もその仲間入りをしつつあ る。その単語の規定する概念などについては今までのと ころ万人共通のものとなっていないし，また明確でない 面も多い。したがって, 公式とか定義を尊重される向き には, 満足と納得の行く状態にはなっていないので, 言 葉として定着しきったとはいえない。

科学技術会議の発表した「ライフサイエンス懇談会報 告」のまえがきには, 生命現象あるいは生物の諸機能に ついての基礎的知見は近年飛躍的に増大し，いわゆるラ イフ・サイエンスといら新たな分野が発展してきてい る。ここれ自然のなかの生命そのものの理解を通して 新しい応用分野の展開につながるものであり, その成果 は直接人間生活に貢献するものと期待されている”之述 べられている1”。

米国の国立科学財団 (National Science Foundation) は, 科学の分野を 7 つの大分野に分けて, そのひとつに Life Sciences を使っている ${ }^{2)}$ 。㠹容とするところ は, 生物学, 医学, 薬学等の生物々生命過程の研究を行 う分野はすべて含められているが，心理学はその中に入 らない。フランスの国立科学研究ャンター (CNRS) で は, 所轄の研究所分類のカテゴリーとして, 生命の科学 Sciences de la vie を使っているが, その中には, 分子 生物学研究所, 発生学研究所, 実験動物選択飼育センタ 一, 食料飼料開発七ンターなどが含をれており, 臨床医 学的なものは含めら机ていない。緑の空間確保の研究セ ンターなどが入っていることから考えて, 医学以外の面i では, フランスのこの範囲は米国のライフサイエンスよ りも多少応用指向の色彩があるともいえる。

いずれにしても, 生物一生命に関する理解がおくれて いることに基づく数多くの問題と, その解決の必要性と
緊急性についての認識が高まっていることと，政府での 研究推進が活発化していることは各国に共通して見られ るところである。次に, ライフサイエンス, あるいは類 似の言葉が用いられる場合, それは, 過去に発展し, 細 分化をしてきたいくつかの学術体系の各分野を含めた形 で使われていて, しかも, 峳密な意味では, 純科学のみ を指していないで, 応用分野もそこに包含された意味あ いがあるように思われる。こうした傾向は, しかし, ラ イフサイエンス分野にのみ個有の現象ではなく, 科学技 術の領域のどこにでもあることではなかろらか。すなわ ち, 応用研究が具体的に実施されて行く道程を考えな がら必要とされる要素を土台にシステムを考える行き方 が, 研究開発の比較的初期段階から求められているわけ で，そらした行き方を体系つけようとすれば旧来の分野 を集約統合しながら，それぞれの分野の相互協力とい。 たものの役割が重要になってくるのである。(マルチ, ディシプリナリーからインターディシプリナリー研究一 といってょかろう。) それが, ライフサイエンス領域に ついては, 生物一生命過程についての理解それ自体が集 約され統合されて行か叔ばならず, 逆にそのシステム化 が新しい局面の打開につながるような期待がもてること も当然である。

そこで, 本文では, ライフサイエンス分野と油化学の 接点となっているいくつかの話題をとらえることによっ て, 前者の中心的研究課題や動向を具体的に述べ, また 研究推進に㧍けるいくつかの問題も指摘したい。

\section{2 油脂類と生物}

油脂類の古い性格のけによれば，水に溶けないで，炭 素数の多い脂肪酸構造をもち, 生物に利用されらるもの とされている。化学的にはこの二番目の性格でのみ脂質 として定義されらるものである。生物側から見れば, ほ とんどの油脂原料に生物が利用されているが，20世紀 
になって、いわゆる生物化学 biochemistry の発展によ って, 脂肪類化合物が単に栄養的なエネルギー貯蔵の形 態であるばかりでなく, 生物における各種の機能発現や 調節機能と密接に関連していることがわかってきた ${ }^{33}$ 。 科学的な発見などの歴史的な背景は別として, 今日的な 話題となったもののなかから, 油脂類と比較的関連のあ ることと, 化合物名などを模式的に表したのが 図-1 で ある。この図の下の方に生物利用を記してあるが，いう までもなく, 生物それ自体の利用はこれまでにも油脂原 料としての生物体があったが, より積極的に発酵法や酸 素を利用することは，「ものを作る」場合には生物反応 の特徵を生かす点で有利な面がある。その反応条件と反 応の選択特異性は, 一般的な化学反応では得られない。

作ることにおける生物の貢献よりも，広範囲にわたる 知識の必要は, この図にも示されたように, 有効性と安 全性であるといってよい。すなわち, 食品として物質が 人間や動物の体内に直接入る場合はもちろん, 薬品とし て経口的だけでなく接触する場合に限らず，環境中に物 質が拡散して行った場合も含めて, その物質の安全性が 確認されなければならぬことは今日常識化している。病 気についても，原因となる物質や現象などについての知 見が増加してきているので, 保健的な観点から制限した り，また新たな治療法のみちが開けつつあるといえる。 ところで, 有効性とか有害性とかは, 科学的な実験デー タそのものではなくて, 社会的, 経済的な要因も含めて なされる人間の判断である。かつ, 定量的なものである が,こうした判断の基盤としては, 物質の場合に限定し て考えるが, 物質が生物と接触した場合に起こる生物側

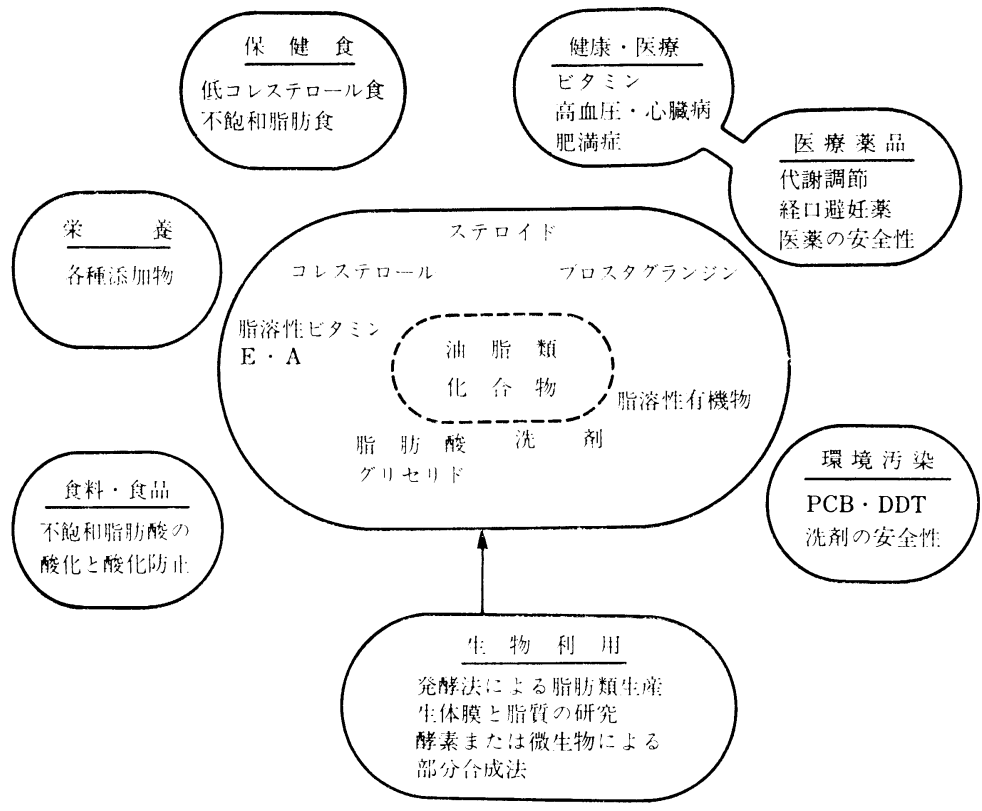

図-1 油脂化合物と人間
の反忘（レスポンス）に関する定星的な情報が必要亡な るのである。またそうした現象が起こる生物の種類を明 確に知ら㸚代ならない。医薬の場合にも所期の活性以外 で作用が表れた時には副作用となり，また，人間以外の 生物で実験をした場合の成果も人間にあてはめる問題が ある。さらには工業薬品などに見られることであるが， 生態系全般への影響と人間との関係などきわめて広範囲 の生物に与える作用ーレスポンスの知見を集積しなけれ ばならぬ。今日的な話題の基盤は, こうした物質と生物 のレスポンスにあるといえる。またそれらのレスポンス を集約していかに判断するかにあるといえる。こうした 「評価」することをシステム化するのは，広範囲の分野 に見られるが，その「評価する」ことの基礎情報として の生物のレスポンスについての知見は重要である。

\section{3 安 全 性}

こうした評価することのなかでも，基本的な問題であ り, かつまた複雑困難なのは安全性であろう。医薬品の ように，元来その物質が人間に与えることを目的として 開発される場合には，逆にその制御む比較的可能である のに対して，一般化学薬品などにおいては制御の方法に ついても実現性がとぼしいことが多ぐ)，またこれまで の研究成果からは，制御が手おくれであったようなでき 事も少なくない。しかし，これまでの幾つかのケースは 今後の安全性研究に幾つかの示唆を残したものといえ る。

第 1 は物質の自然界を含めて人間との接触径路に関す る問題である。DDT およびその誘導体が, 自然の食物 連鎖を通じて濃縮されるといわれ ている。しかしその濃縮率は魚の 場合には数百倍であるとされてい るが, 魚の食物の摂取量と成長な どのデータからは，たかだか十倍 くらいの濃縮度しか期待できな い。したがって，水中から，えら を通って血液を通って体脂肪に蓄 積される径路を考虑せざるを得な い5)。こうした例は毒性の発現の 可能性を検討して行く上に極めて 重要である。物質によっては, 腸 の表面で分解されたり, 吸収に選 択性があって食物として提攻され たり，経口的念投与法では生物活 性を示さないか，ないしは弱い上 いら例が考えられる。パーキンソ ン氏病の治療剂として知られる L-DOPA は経口投与されても小 腸の脱炭酸酵素によって分解され 
るためにそのままの形で脳に到達し難いので効果を現さ ない。DDT は動物の消化器内で DDD などの誘導体 に変化して行くことが知られていて，それらの誘導体は それぞれ異なった毒性をもっているので，当然のことな がら，動物が接触する場所や形態がどの動物でも同じと 考えられない。したがって有害性に当然差があり得よ う。

第 2 は, 物質の純度や不純物の構造に関する問題であ る。PCB はそれ自体塩素化度の異なった biphenyl の 混合物であり，構造によって毒性が相異なることも知ら れているが,さらに，不純物として存在するダイオキシ ン体は塩素化されただけのものよりもはるかに靚性が強 いといわれている6)。<smiles>ClCC1COC2OC(CCl)CC(Cl)COC2C1</smiles>

图-2 ダイオキシンの例

この 2 つの問題だけから考えて, 洗凨の毒性試験は極 めて興味深い。まず接触（暴露）径路であるが, 普通の 使用方法を見るならば，溶液にして手でふれることが最 も多いので，経皮吸収があると考えられる。ちいさい傷 があった場合のことを考えれば，皮下注射と同じような 径路が考えられる。食器や野菜の洗浄に使ったものが残 存していれば当然経口である。一応物質そのものの変化 を考慮しなくても，これだけの径路の実験は必要になっ て来よう。あくまで動物を用いた実験結果であるが，経 口投与と皮下投与と経皮吸収とでは洗剤の毒性発現に相 異が見られている。肝障害などの観察では ABS 経皮吸 収が瑇性発現が強いといわれている。次に第 2 の問題で あるが，ABS や LAS を主剤とする洗剤の助剂や不純 物についての物質の情報がほとんどなく, 毒性を評価す る手がかりが少ない。今後この面での検討が進められね ばならない。図-3 のような物質には発がん性のあるこ とが知られていて, oletinosulfone についての生物活 性や物質の構造の詳細な検討が必要とされよう。<smiles>C[C@@H]1CS(=O)(=O)O1</smiles>

図-3
第 3 の安全性の問題は，実験 動物の種による差を充分考虑し なければならぬことである。一 部の化学物質の人間に対する有 害性は，人体での事故として報告されたので，動物実験 の結果と人間の結果を対比させることは可能であるが， もともと大きな代償のうえで，一部にそうしたデータが 存在するのであって, 今後実験的にこれを数多い化合物 で繰り返すことは許されないのである。ところで, 洗剈 の場合を人間にあてはめて考えようとすれば，動物実験 の成果をそのまま用いることはできないことは明白であ る。第 1 亿は皮膚の構造の差は, きっ歯類と人間ではか なり大きいので, 構造の差からくる経皮吸収の速度や量 にかなりの差があることは想像できるがデータがない。
第 2 に, 動物には化学物質を無毒化したり分解する代謝 径路があって，それが動物の種による差が著しい。した がってある動物で観察された現象が他の動物で観察され ないことがあり，人間に関してはそうした機構について 他の動物との差が明確にされない面が多い。仮りに，動 物によって解毒速度に大きな差があれば,一方では毒性 が観察され，他方の種では同じ量が与えられても毒性が 見られないのである。

人間を対象にしない場合でも，生態系への影響を考え る場合に種差を考えることは必要である。魚に対する毒 性試験法はある程度普及してきたとはいえ，いわゆる けっ歯類を中心としたほ (哺) 乳類の実験法に比べて未 発達である。TLm 96 など急性毒性を試験する場合でも，

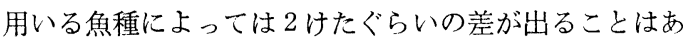
たりまえとさえいわれている。まして，漁業資源を考え るような場合にはむしろ慢性的な有害可能性汇言及せね 洂ならず，また，その具体的な水系汇関する経済的な重 要魚種にも差があるので, 試験結果と実際とを連絡して 行くための研究も必要となろう。たとえば, 特定魚種を 環境監視のための検出端に用いた場合, 実際にはその地 域の魚種が指標魚よりも毒性物質に対する感度が確実に 低い場合は問題がないが，その逆は成り立たない。一般 に,コイはニジマスよりも鈍感であるといわれている。

さきに, 安全性（有害性）は人間の判断であることを 述べたが，その判断の因子としては，社会的，経済的な ものが含まれるが，判断の基礎資料を科学が提供すると も述べたが，実際には判断根拠と科学の発達度，信頼度 との間には相関性があるといえる。生物を用いた検出法 は，毒性試験そのものとは異なっているのが当然であ る。というのは, 慢性暴露によって起こる障害は一代で 止らず次の世代以降に与えられる影響などは毒性試験で 充分検討され㸚ばならないとしても，試験は時によって 2 年以上にわたる場合があり，環境監視法としては時間 がかかりすぎるので，指標としてはより短時間で発現す るような現象を選択することになる。また，生物によっ て示されるレスポンスには個体差があって，実際には数 匹の被験動物のうち何匹かにレスポンスが見られた場合 汇それを有意の差とする。魚を用いた重金属の検出法7 の場合には，4匹中の 2 匹のレスポンスを基準とする場 合と 4 匹中 3 匹のレスポンスを基準とした場合では，検 出されたと判定できるまでには時間が $24 \mathrm{hr}$ も異なる が，その反面 4 匹中 3 匹の場合には見られなかった誤認 が生じ得る。すなわち,その重金属がない場合でも異常障 害と同じような現象が観察さ机ることがある。したが。 て，その基準を工場運転などに適用するとすれば，感度 が悪いが確実な $3 / 4$ を規準にした場合レスポンスが認 められた場合には工場閉鎖とかプロセス転換は行う必要 が出てくる。それに対し2/4ではレスポンスが誤認でな 
いことを再榆討する間排出物を貯留しておくような必要 も生じるが，それが誤認なら代問題ないことになる。し たがって，生物指標による検出とその実際面での刘処の 仕方注方法の性質で異なってくるのが当然であり, 基蕉 のおきかたも大切なのである。

裂約す机ば，安全性の試験は実際には確立した方法は なく，判断についても確立していない。したがって特定 の物質の安全性評価を行うためには，そのケースに応じ た実験方法と評価基準を適用しなければならない。試験 方法の一部には確立したルーティン試験もあるが，全体 は決してルーティン化され得ない性格をもっていて, 重 要な研究課題なのである。方法の確実度を上げること自 体大きな研究である。さらに, 実験用の動物はこれまで の医薬品の病態モデル動物のように特別の種が選択され ることも必要なことであり,さもなければ, 試験データ がたくさんあっても，実際淌での対策につながらないお それもあろう。

\section{4 健 康と食}

人間を中心として動物は必要な栄養物を自身の体内で 作り出すことができないで, 必要な栄養素を食事の中か ら摂取する必要があり，その代表的化合物は必要アミノ 酸やビタミン類であるが, さらに, 不飽和脂肪酸の重要 性などが知られ，とくに成人病と脂肪酸の構造やビタミ ンなどの相関性の研究が盛んになった。それらの成果の 詳細については専門的な論文などにゆずるがここで特 記すべきことは, 健康管理や疾病の治療における食事の 制限の重要性である。心臓病の患者のための不飽和脂肪 食は今日では公共的なサービスでも入手できるほど普及 してきた。今後こらした分野でのアプローチとして注目 すべきものに 2 種類ある。その第 1 は腸管での選択吸収 性付与であり，第 2 は構成食品 (fabricated food) であ ろう。

腸管に扔ける物質の吸収は化学構造的に選択があるこ とが知られている。D-アミノ酸と L-アミノ酸を与えて も， $\mathrm{L}$ 型のみが選択され能動的に吸収される。脂肪酸の 吸収の問題についても研究が多い(8)。そこで, 飽和脂肪 酸についての吸収をのみ制限する方法が見いだされれ 壮，食品そのものを心配する必要がなかろうというもの であるが，この方法の具体的実現性があまり有望でな い。そこで，第 2 の方法がむしろ可能性としては高く, 飽和脂肪酸だけでなく, 各種の栄養的な修飾を食品に加 えるアプローチとして見られる ${ }^{9}$ 。すなわち，索材とな る食品を抽出分離の方法で必要な純化を行って一たん原 料素材を使い, 次にこれらを用いて新しい型の食品に組 み立てるものである。この原理によれば望ましくない成 分を除去したり必要なものを添加したりすることは自由 に行いうるはずである。しかしながら, 加工度が増加す
ることは，これまでの食習慣とあるていど戊対の要素で あると見てよいので，これも実現性は容易ではない。

脂肪類物質の化学構造と生理的な意義については目下 も研究が進展しつつあり, 部分的発展の成果としても保 健上食事については脂肪類の関係が重要であることが確 実であるので今後この分野に注目したい。

\section{5 人口調節}

社会的に見れば, 人口調節は数多くの側面や問題点を 含んでいる。世界的なスケールでは人口増加と食料供給 のアンバランスから，世界的な人口制御が実施されるべ きであるともいえる。開発途上国の一部においては，す でに人口増加率の低下を推進した国もあるが満足すべき 状態に達していない。また個人的な段階においても, よ り良き家族計画とその実施が必要であることは認識され たこととして良い。しかしながら, 受胎調節法や産児制 御法については, 既存の方法がまだ改良の余地があると いえよう。

この分野で着目されている物質の主流はステロイド系 ホルモンとプロスタグランジンである。ステロイド系の 経口避妊薬はその性質から副作用について疑問がのこっ たことと, 毎日摂取しなければならないという不便さと から新しい開発の段階に入ったといえよう。副作用や慢 性的な障害検討のために, 米国においてはサルを用いて 25 年間の実験が進められているが現在その半ばを過ぎ たていどである。サルによるこのような長期の実験の意 義については確実な科学的背景があったかどうかは別と しても, 作用機作から考えても長期慢性障害が検討の重 要項目となるのは当然である。しかし，こうした問題の 解決法として, ひとつは, これまでの投与量よりもはる かに低い濃度によって同様の効果をもちうるとする，い わゆるミニピルが出現した。有効濃度を下げても有効性 についてはそれほど低下しないことが知られるにいた り，連日の摂取をしなくても済むような製剤技術が進歩 しえよう。今のところアイディア段階であるが, プラス チックス薄膜で薬剤を包み, それを皮下に植え込むこと で薬剤が生体中に入るのを徐々にしてかつ持続させよう とするものである。こうした方法によって，1 週ないし は 1 か月に 1 度の交換で目的を達することができ, 血中 や生体各部分の有效濃度を必要最低に保てるとされてい るが，具体的な実施にはいたっていない。

プロスタグランジンについての研究はここ数年急激な 発展があったが, この化合物群の成分の純化之結晶化, それに生物活性による検出法の進歩などは, プロスタグ ランジンの科学が, 化学とも生物学とも, また薬理学と も分解されず総合的な領域として進歩してきたことを物 語っている。今のところ, プロスタグランジン化合物群 についてはホルモンとしては取り扱われていない。この 
詳細な部分についてはここでは触れないが1(1), 子宮筋の 吸縮作用があり，また黄体機能との関連があることなど から，受胎調節剤としての可能性に着目されたが，これ までのところあまり有望になっていないで，むしろ，そ れ以外の機能での開発が進んでいる。

\section{6 おわりに}

これまで述べてきたことや，図-1 に表したことは， 油脂類と生物の相関を示すほんの一部分を示したにすぎ ない。化学上の進歩は分析や構造 ・ 反応の面で急激な進 歩を遂げつつあり, 他方, 生物体内での油脂類の変化を 追跡するにあたって大きな貢献をしつつある。生物側か らの研究成果はこれらの物質の生理活性についても詳細 な知見を収集しつつある。これらの情報が基盤となって 今後の発展が大いに期待されるところである。くり返し になるが, しかし, 有効性や安全性などの問題について の基盤を固めて行く意味でも, また応用の具体的な展開 という立場をとっても, 旧来の化学的な研究と生物学的 な研究とが総合化されて人類の進歩や生活の充実に密接 した結果を生みだされることを念じて筆をおく。
最後に、この機会を与えて下さった編集者諸氏に厚く お礼を申し上げると共に, 読者諸兄の御批判と御教示を 切に打願いする次第である。

(昭和 49 年 6 月 11 月受理)

\section{文献}

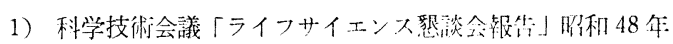
7 月 (1973)

2) 米国科学財団 (US・NSF)

3）瓜谷ら編「脂質とその周辺」(1970) 共立出版社.

4) Dixor, R.L. Environmental Health Perspectives, 2, 103 (1972)

5) 藤谷, 私信

6) A. Poland, E. Glover, Science, 179, 476 (1973)

7) Glass, G.E. ed. "Bioassay Techniques and Environmental Chemistry”, p. 383 (1973), Ann Arbor Science pub.

8) Frazer, A.C. ed. "Biochemical Problems of Lipids" (1963), Elsevier Pub. Co.

9) SRI, "Fabricated Food", Long Range Planning Report No. R374 (1969)

10）医学のあゆみ，81（5)，(1972).「プロスタグランジ บ」 